\title{
Trust in One's Physician: The Role of Ethnic Match, Autonomy, Acculturation, and Religiosity Among Japanese and Japanese Americans
}

\author{
Derjung M. Tarn, MD, MS \\ Lisa S. Meredith, $\mathrm{PbD}^{2}$ \\ Marjorie Kagawa-Singer, $R N, P b D^{3}$ \\ Shinji Matsumura, MD, MSHS \\ Seiji Bito, MD, MSHS \\ Robert K. Oye, $M D^{6}$ \\ Hongbu Liu, PbD ${ }^{6}$ \\ Katherine L. Kabn, $M D^{6}$ \\ Shunichi Fukubara, $M D^{7}$ \\ Neil S. Wenger, $M D, M P H^{6,8}$ \\ 'Department of Family Medicine, David \\ Geffen School of Medicine, University of \\ California, Los Angeles, Calif \\ ${ }^{2}$ RAND Health, Santa Monica, Calif \\ ${ }^{3}$ School of Public Health and Asian \\ American Studies, David Geffen School of \\ Medicine, University of California, \\ Los Angeles, Calif \\ ${ }^{4}$ University of Tokyo, Tokyo, Japan \\ ${ }^{5}$ National Tokyo Medical Center, Tokyo, \\ Japan \\ ${ }^{6}$ Division of General Internal Medicine \\ and Health Services Research, David Geffen \\ School of Medicine, University of California, \\ Los Angeles, Calif \\ ${ }^{7}$ Kyoto University, Kyoto, Japan \\ ${ }^{8}$ UCLA Healthcare Ethics Center, David \\ Geffen School of Medicine, University of \\ California, Los Angeles, Calif
}

\section{Conflicts of interest: none reported}

\section{CORRESPONDING AUTHOR}

Derjung Mimi Tarn, MD, MS

UCLA Department of Family Medicine 10880 Wilshire Blvd, Suite 1800

Los Angeles, CA 90024

dtarn@mednet.ucla.edu

\begin{abstract}
PURPOSE Trust is a cornerstone of the physician-patient relationship. We investigated the relation of patient characteristics, religiosity, acculturation, physician ethnicity, and insurance-mandated physician change to levels of trust in Japanese American and Japanese patients.
\end{abstract}

METHODS A self-administered, cross-sectional questionnaire in English and Japanese (completed in the language of their choice) was given to community-based samples of 539 English-speaking Japanese Americans, 340 Japanese-speaking Japanese Americans, and 304 Japanese living in Japan.

RESULTS Eighty-seven percent of English-speaking Japanese Americans, 93\% of Japanese-speaking Japanese Americans, and 58\% of Japanese living in Japan responded to trust items and reported mean trust scores of 83,80 , and 68 , respectively, on a scale ranging from 0 to 100. In multivariate analyses, Englishspeaking and Japanese-speaking Japanese American respondents reported more trust than Japanese respondents living in Japan $(P$ values $<.001)$. Greater religiosity $(P<.001)$, less desire for autonomy $(P<.001)$, and physician-patient relationships of longer duration $(P<.001)$ were related to increased trust. Among Japanese Americans, more acculturated respondents reported more trust $(P<.001)$, and Japanese physicians were trusted more than physicians of another ethnicity. Among respondents prompted to change physicians because of insurance coverage, the $48 \%$ who did not want to switch reported less trust in their current physician than in their former physician (mean score of 82 vs $89, P<.001$ ).

CONCLUSIONS Religiosity, autonomy preference, and acculturation were strongly related to trust in one's physician among the Japanese American and Japanese samples studied and may provide avenues to enhance the physician-patient relationship. The strong relationship of trust with patient-physician ethnic match and the loss of trust when patients, in retrospect, report leaving a preferred physician suggest unintended consequences to patients not able to continue with their preferred physicians.

Ann Fam Med 2005;3:339-347. DOI: 10.1370/afm.289.

\section{INTRODUCTION}

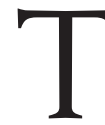

rust between a patient and physician is a cornerstone of the patientphysician relationship. ${ }^{1,2}$ Trust can facilitate health information exchange, ${ }^{3}$ as well as determine a patient's willingness to seek care, ${ }^{3,4}$ receptivity to health promotion counseling ${ }^{5.7}$ openness to examination and treatment, ${ }^{4,5,7-11}$ and likelihood of return for follow-up care. ${ }^{5,10}$ Patients with more trust in their physician are likely to be more satisfied with care, ${ }^{5,11-14}$ and to have positive clinical outcomes. ${ }^{5,9,11}$ In recent years, patient trust has been challenged by perceived conflicts of interest inherent in managed 
care $^{8,15-20}$ and by societal changes leading to increased patient autonomy and information access. In an era of increased cultural diversity and potential language barriers, trust is crucial for patients struggling to accept diagnoses and to follow complex treatment plans.

Despite the important role of trust in the physicianpatient relationship, there are considerable gaps in our understanding about factors underlying patient trust in their physicians. Conceptually, physician characteristics and behaviors, patient demographics and clinical factors, patient view of the physician-patient relationship, and characteristics of the relationship, all combine to influence trust in one's physician. Previous studies identified physician behaviors related to patient trust, such as technical competency and good interpersonal skills. ${ }^{21,22}$ Other important determinants of trust include physician office structure and staffing. ${ }^{21,23}$ Increased patient age is related to a higher level of trust in physicians, ${ }^{10,20-22,24}$ but it is unknown whether patient desire for autonomy or religiosity (both related to age) play a role in this finding. The characteristics of patient sex, ${ }_{1}^{10,11,20,24-26}$ education, ${ }^{10,11,20,26}$ and income ${ }^{11,24}$ have weak or nonexistent relationships with trust. One study suggests that patients with worse physical and mental health status have less trust in their physician. ${ }^{27}$ Continuity of care ${ }^{21,22}$ and increased duration of the physician-patient relationship ${ }^{10,20,24,28}$ are associated with increased trust. Patients given a choice of physicians also tend to be more trusting. ${ }^{20}$ Little is known, however, about whether such cultural factors as patient-physician ethnic match and acculturation affect trust.

We performed a cross-cultural survey of a single ethnic group to understand how predisposing patient factors, cultural issues, patient-physician relationship characteristics, and insurance-mandated physician change affect patients' trust in their physicians. Based on the literature and clinical experience, we specified a priori a set of predisposing patient variables that we expected would be related to trust. We hypothesized that persons desiring more autonomy ${ }^{3,29,30}$ would be less trusting of physicians. We also anticipated that married persons and those with greater religiosity would have greater trust. Those with increased acculturation to Western mores and an ethnic match with their physician also would be more likely to have increased trust, because language and cultural obstacles would be less formidable. Patients required to change physicians because of insurance mandates might be less trusting of their new physicians.

\section{METHODS}

We surveyed older persons of Japanese heritage to understand the determinants of trust. Three cohorts of Japanese were identified: 1 cohort of Japanese living in Japan, and 2 groups of Japanese Americans representing different levels of acculturation. Consistent with validated acculturation scales, Japanese language fluency was used as a proxy for acculturation. ${ }^{31-33}$ Less acculturated Japanese-speaking Japanese Americans were sampled from settings geographically distributed around Los Angeles: 2 apartment complexes in Little Tokyo (a Japanese enclave established by older generations), 2 social clubs for older Japanese, and 2 Japanese American social organizations. More acculturated English-speaking Japanese Americans were randomly sampled from member lists of 3 geographically distinct Japanese American community centers in the Los Angeles area. Japanese living in Japan were either members of social clubs or older family members of workers at a hospital in Nagoya, Japan.

\section{Survey Procedure and Contents}

The survey questionnaire was administered in 1997 for English-speaking Japanese Americans and in 1998 for Japanese-speaking Japanese Americans and Japanese living in Japan; it was mailed in the United States and hand-delivered in Japan. Nonrespondents were sent a postcard reminder and a second mailing. The survey protocol was approved by the Institutional Review Board at the University of California, Los Angeles. Five hundred thirty-nine English-speaking Japanese Americans, 340 Japanese-speaking Japanese Americans, and 304 Japanese living in Japan responded to the questionnaire for response rates of $92 \%, 82 \%$ and $91 \%$, respectively. Of these, 467 English-speaking Japanese Americans (87\%), 315 Japanese-speaking Japanese Americans (93\%), and 175 Japanese living in Japan (58\%) responded to trust items.

The self-administered questionnaire contained several previously validated scales. ${ }^{34-36}$ An English language version of the questionnaire was initially developed based on findings from focus groups with Englishspeaking and Japanese-speaking Japanese Americans and Japanese living in Tokyo. ${ }^{37}$ The Japanese language questionnaire was constructed by forward and backward translation. The questionnaire included the SF-12 Health Survey ${ }^{38}$ items modified from a validated Japanese version of the SF-36, ${ }^{39,40}$ and a Japanese language version of Ende's Autonomy Preference Index.. ${ }^{41,42}$ The survey instrument development is discussed in greater detail elsewhere. ${ }^{43}$ Japanese living in Japan completed the Japanese language version, English-speaking Japanese Americans completed the English language version, and Japanese-speaking Japanese Americans completed the questionnaire in the language of their choice, with most selecting the Japanese version.

The questionnaire elicited demographic information and information about religion. To investigate religious affiliation and level of religiosity, we asked respondents whether they thought of themselves "as a religious per- 
son," and whether they were "officially a member of a parish, congregation, temple, or other place of worship." Clinical factors included the SF-12 physical and mental health components measuring health-related quality of life (HRQOL), the number of chronic health conditions, and whether the patient was hospitalized in the past 6 months. The Autonomy Preference Index (API) assessed desired level of autonomy in decision making $(\alpha=0.86)$.

Respondents were asked whether they had a regular physician and the duration of the relationship with that physician. Japanese Americans were also asked whether they had been "forced to change doctors due to ... insurance coverage in the past 5 years," if they wanted to "continue seeing [their] prior doctor," how long they had seen their previous physician, and current and previous physician ethnicity.

Japanese Americans also completed 6 items measuring acculturation $(\alpha=0.82)$. The scale was highly correlated $(r=0.71)$ with a longer instrument, the Suinn-Lew Asian Self-Identity Acculturation Scale, ${ }^{31-33}$ and yielded scores ranging from 0 to 100 ( $100=$ maximum acculturation $)$. Items included the respondent's preferred language, selfdesignated ethnicity, country of birth, country of rearing, and number of foreign-born parents and grandparents. ${ }^{33}$

\section{Measurement of Trust}

Respondents were asked 3 questions about the amount of trust they had in their physician: "How much do you trust your doctor to provide you high-quality medical care?" "How much do you trust your doctor to always make medical decisions in your best interest?" and "How much do you trust your doctor to provide you with the amount and kind of medical care that you would want if you were critically ill?" Response options included not at all, a little, somewhat, mostly, and completely ( $1=$ not at all, 5 = completely). These items were adapted from a previously validated 10 -item scale designed to investigate the influence of payment method on trust. ${ }^{12}$ The 3 items were formed into a trust scale with $\alpha=0.92$ ( $\alpha$ $=0.91,0.93$, and 0.91 for English-speaking Japanese Americans, Japanese-speaking Japanese Americans, and Japanese living in Japan, respectively). If respondents answered only 2 trust items $(n=11)$, these items were used to form the trust scale. This scale was transformed to a 0 to 100 score by subtracting 1 from the mean score and multiplying the result by $25 .{ }^{11}$ Findings from this sample suggest that trust increases 1 point for each year of physician-patient relationship.

\section{Statistical Analysis}

We performed bivariate analyses to assess the relationship between patient characteristics and trust with correlation coefficients, $t$ tests, and analysis of variance, as appropriate for continuous and categorical measures.
Continuous variables included age, education, mental and physical HRQOL, number of chronic conditions, duration of relationship with physician (in years), API (on a scale from 1 to 5 , with 5 = greatest desire for autonomy) and acculturation score. Categorical variables included sex, marital status, household income $(\$ 1=¥ 140),{ }^{44}$ religious affiliation, religiosity (not religious, religious but not a church member, or religious church member), health insurance, recent hospitalization, physician ethnicity, and study cohort.

All the variables selected for the bivariate analysis were included in a multivariate model, with the exception of income, health insurance, and number of chronic conditions, which were not significantly correlated with trust in bivariate analyses and were highly correlated with other independent variables. We used multistep multiple linear regression. The first model contained demographic variables only. Then clinical variables (hospitalization and HRQOL) were added to the model. Subsequently, API and physician-patient relationship duration were added. The results of only the full model and the model containing demographic and clinical characteristics are presented because adding clinical variables to the demographic model caused little change. Missing physical and mental HRQOL items ( $\mathrm{n}=151)$ were replaced using mean substitution. A separate multivariate analysis was performed with Japanese Americans using the same multistep approach; acculturation and physician ethnicity were included in this full model. Model goodness-of-fit was evaluated using adjusted $R^{2}$. Two respondent outliers were excluded from the analyses; deletion had minimal effect on regression variable parameter estimates or significance levels.

A separate analysis examined the effect of changing physicians and physician ethnicity on patient trust. Change in trust was computed by subtracting trust in current physician from trust in previous physician. Change in trust by physician ethnicity was evaluated for patients who had to change physicians, comparing those who preferred not to change physicians with those who found change to be acceptable. We performed $t$ tests and Wilcoxon nonparametric 2-sample tests, as appropriate, to assess changes in trust within and between the 2 groups. Multivariate analysis was used to explore the relationship between change in trust (the dependent variable) and patient demographics, clinical variables, API, acculturation, physician-patient relationship duration, current and previous physician ethnicity, and patient desire to continue with previous physician.

\section{RESULTS}

The sample included 467 English-speaking Japanese Americans, 315 Japanese-speaking Japanese Americans, 


\begin{tabular}{|c|c|c|c|}
\hline Characteristic & $\begin{array}{c}\text { English-speaking } \\
\text { Japanese } \\
\text { Americans }\end{array}$ & $\begin{array}{l}\text { Japanese-speaking } \\
\text { Japanese } \\
\text { Americans }\end{array}$ & $\begin{array}{l}\text { Japanese } \\
\text { Living } \\
\text { in Japan }\end{array}$ \\
\hline Number & 467 & 315 & 175 \\
\hline Mean age, y $(S D)^{*}$ & $64.5(13.5)$ & $74.7(9.1)$ & $65.8(8.6)$ \\
\hline Male, \%* & 61.7 & 35.1 & 40.2 \\
\hline \multicolumn{4}{|l|}{ Marital status, \%* } \\
\hline Married & 70.0 & 50.7 & 76.4 \\
\hline Divorced or separated & 5.6 & 10.4 & 6.9 \\
\hline Widowed & 19.9 & 33.3 & 14.4 \\
\hline Never married & 4.5 & 5.6 & 2.3 \\
\hline $\begin{array}{l}\text { Household income } \\
\leq \$ 50,000, \% * \dagger\end{array}$ & 58.4 & 84.6 & 79.3 \\
\hline Working, \%* & 43.5 & 23.1 & 35.3 \\
\hline $\begin{array}{l}\text { Mean years of } \\
\text { education (SD)* }\end{array}$ & $14.1(2.9)$ & $11.5(2.6)$ & $11.3(2.6)$ \\
\hline \multicolumn{4}{|l|}{ Religious affiliation, \%* } \\
\hline Christian & 37.1 & 14.3 & 2.9 \\
\hline Buddhist & 47.7 & 61.5 & 70.4 \\
\hline No specific affiliation & 13.1 & 19.3 & 24.4 \\
\hline Other religion & 2.2 & 5.0 & 2.3 \\
\hline \multicolumn{4}{|l|}{ Religiosity, \%* } \\
\hline Not religious & 48.6 & 47.0 & 57.6 \\
\hline $\begin{array}{l}\text { Religious, not a church } \\
\text { member }\end{array}$ & 16.3 & 23.0 & 27.3 \\
\hline Religious, church member & 35.1 & 30.0 & 15.1 \\
\hline \multicolumn{4}{|l|}{ Health Insurance, \%* } \\
\hline National insurance & NA & NA & 100 \\
\hline Medicare & 41.5 & 32.8 & NA \\
\hline Private & 55.7 & 46.8 & NA \\
\hline $\begin{array}{l}\text { Medicaid alone/no } \\
\text { insurance }\end{array}$ & 2.8 & 20.4 & NA \\
\hline Have a regular doctor, $\%^{\ddagger}$ & 99.8 & 98.0 & 100 \\
\hline \multicolumn{4}{|l|}{$\begin{array}{l}\text { Ethnicity of regular } \\
\text { doctor, \%* }\end{array}$} \\
\hline Japanese & 35.7 & 66.2 & NA \\
\hline White & 40.2 & 12.8 & NA \\
\hline Other Asian & 17.0 & 19.0 & NA \\
\hline Other ethnicity & 7.2 & 2.0 & NA \\
\hline $\begin{array}{l}\text { Mean years with regular } \\
\text { doctor }(\mathrm{SD})^{\ddagger}\end{array}$ & $3.5(1.3)$ & $3.7(1.3)$ & $3.8(1.1)$ \\
\hline $\begin{array}{l}\text { Autonomy Preference } \\
\text { Index (SD) })^{\star \S}\end{array}$ & $3.1(1.2)$ & $1.7(0.8)$ & $2.3(0.99)$ \\
\hline $\begin{array}{l}\text { Mean acculturation } \\
\text { score }(S D)^{* \|}\end{array}$ & $69.1(23.8)$ & $26.0(23.7)$ & NA \\
\hline \multicolumn{4}{|l|}{ HRQOL, mean (SD) } \\
\hline Physical summary score* & $48.9(9.6)$ & $47.1(8.8)$ & $46.2(8.5)$ \\
\hline Mental summary score* & $53.6(7.8)$ & $49.8(8.8)$ & $45.6(7.5)$ \\
\hline $\begin{array}{l}\text { Mean number of chronic } \\
\text { conditions (SD) }\end{array}$ & $2.2(1.7)$ & $2.0(1.6)$ & $2.0(1.5)$ \\
\hline $\begin{array}{l}\text { Hospitalization in past } \\
6 \text { months, } \%^{\ddagger}\end{array}$ & 6.2 & 12.6 & 9.1 \\
\hline $\begin{array}{l}\text { HRQOL }=\text { health-related quality o } \\
* P<.001 \text {. } \\
\text { † Japanese yen converted to US } \mathrm{d} \\
\text { f } P<.01 \text {. } \\
\S \text { Autonomy Preference Index ran } \\
\text { ॥ Acculturation score ranges from } \\
\text { \& Health-related quality of life me }\end{array}$ & $\begin{array}{l}\text { ars }(¥ 140=\$ 1) \text {. } \\
\text { from } 1 \text { to } 5 \text {; higher score } \\
\text { to } 100 \text {; higher score indica } \\
\text { red by SF-12 on } 0 \text { to } 100\end{array}$ & $\begin{array}{l}\text { dicates greater autonomy. } \\
\text { s more acculturation. } \\
\text { ale; higher score is better. }\end{array}$ & \\
\hline
\end{tabular}

and 175 Japanese living in Japan. English-speaking Japanese American respondents were more likely to have higher income. Japanese-speaking Japanese American respondents were more likely to be older, female, not working, and either divorced, separated, or widowed. English-speaking Japanese American respondents had the largest proportion of Christians and religious church members, whereas Japanese respondents living in Japan had more Buddhists. Mean physical and mental HRQOL scores decreased from English-speaking Japanese American respondents to Japanese-speaking Japanese American respondents to Japanese respondents living in Japan. English-speaking Japanese American respondents had more chronic conditions than the other groups but fewer recent hospitalizations. English-speaking Japanese American respondents reported the greatest desire for autonomy, followed by Japanese respondents living in Japan and then Japanese-speaking Japanese American respondents. Patient-physician relationship duration was similar across groups. English-speaking Japanese American respondents were more acculturated than were Japanese-speaking Japanese Americans respondents (69 vs 26), and Japanese-speaking Japanese Americans respondents were more likely to have Japanese physicians (Table 1).

Overall, respondents had a mean trust rating of 79 , with a range from 0 to 100 . Thirty-one percent of respondents gave their physician a perfect score, $55 \%$ were 75 years old or older, and $13 \%$ were younger than 50 years. English-speaking Japanese American respondents had a mean trust level of 83 , compared with 80 for Japanese-speaking Japanese Americans respondents and 68 for Japanese respondents living in Japan. 


\begin{tabular}{|c|c|c|c|c|}
\hline Characteristics & $\mathbf{n}$ & $\begin{array}{c}\text { Mean } \\
\text { Trust } \\
\text { Score }\end{array}$ & $R^{2}$ & $P$ Value \\
\hline Group & 957 & & & $<.001$ \\
\hline $\begin{array}{l}\text { English-speaking } \\
\text { Japanese Americans }\end{array}$ & & 83.2 & & \\
\hline $\begin{array}{l}\text { Japanese-speaking } \\
\text { Japanese Americans }\end{array}$ & & 80.3 & & \\
\hline Japanese living in Japan & & 67.5 & & \\
\hline Male & 946 & 80.4 & & .08 \\
\hline Female & & 78.4 & & \\
\hline Age, years & 935 & - & 0.16 & $<.001$ \\
\hline Marital status & 943 & & & $<.001$ \\
\hline Divorced or separated & & 71.9 & & \\
\hline Never married & & 80.2 & & \\
\hline Married & & 78.6 & & \\
\hline Widowed & & 83.9 & & \\
\hline Household income & 872 & & & .70 \\
\hline$<\$ 50,000$ & & 79.3 & & \\
\hline$>\$ 50,000$ & & 78.7 & & \\
\hline Education & 934 & - & 0.00 & .87 \\
\hline Religious affiliation & 932 & & & $<.001$ \\
\hline Christian & & 83.1 & & \\
\hline Buddhist & & 79.7 & & \\
\hline Other; no specific religion & & 74.4 & & \\
\hline Religiosity & 932 & & & $<.001$ \\
\hline Not religious & & 75.9 & & \\
\hline Religious, not a church member & & 79.5 & & \\
\hline Religious, church member & & 85.3 & & \\
\hline Health Insurance & 773 & & & $<.01$ \\
\hline Medicare & & 84.8 & & \\
\hline Private & & 80.3 & & \\
\hline Medicaid only/no insurance & & 81.3 & & \\
\hline Other insurance & & 83.3 & & \\
\hline \multicolumn{5}{|l|}{ HRQOL from SF-12 } \\
\hline Physical summary score & 806 & - & 0.02 & .53 \\
\hline Mental summary score & 806 & - & 0.21 & $<.001$ \\
\hline Chronic conditions & 932 & - & 0.01 & .78 \\
\hline Hospitalization in past 6 months & 934 & 82.0 & & .20 \\
\hline No hospitalization past 6 months & & 79.3 & & \\
\hline Ethnicity of regular doctor* & 765 & & & $<.001$ \\
\hline Japanese & & 84.7 & & \\
\hline White & & 82.1 & & \\
\hline Other ethnicity & & 77.2 & & \\
\hline Years with regular doctor & 940 & - & 0.22 & $<.001$ \\
\hline Autonomy preference index & 901 & - & -0.12 & $<.001$ \\
\hline Acculturation score* & 780 & - & 0.10 & .004 \\
\hline
\end{tabular}

were associated with greater trust. Among Japanese Americans, trust was highest for Japanese physicians. Other demographic and clinical variables were not related to trust (Table 2).

\section{Multivariate Analysis}

In multivariate analyses, English-speaking and Japanese-speaking Japanese American respondents reported significantly more trust than did Japanese respondents living in Japan. Patients desiring less autonomy and those who had longer relationships with their physicians reported more trust in their physicians; inclusion of these 2 variables reduced the relationship of patient age, sex, and hospitalization with trust in the demographic and clinical model, but other variables were minimally affected. Divorced patients reported less trust, but widowed patients had more trust than married patients. Level of religiosity was directly related to trust, as was better physical and mental HRQOL (Table 3).

The multivariate model that included only Japanese Americans differed little from the model that included all 3 groups. More acculturated patients reported significantly more trust. In addition, patients trusted Japanese physicians more than other physicians (Table 4).

\section{Relationship of Changing Physicians and Trust}

Of 782 Japanese American respondents, 307 indicated that they had changed physicians because of insurance reasons in the past 5 years. Of these respondents, 233 reported on whether they wanted to continue seeing their previous physician and indicated the ethnicity of their current and previous physicians. Overall, patients who wanted to stay with their previous physician held greater trust in that physician compared with those who reported that change was acceptable $(89.3$ vs $71.3, P<.001)$. Patients who did not want to change physicians reported significantly less trust in their current physician than in their previous physician ( 81.8 vs $89.3, P<.001)$; however, patients who reported that physician change was acceptable reported slightly higher trust in their current than their previous physician (76.7 vs 71.3 ,

\section{Bivariate Correlates of Trust}

Older respondents and religious respondents held higher levels of trust, especially true for those of Christian faith. Higher mental HRQOL, longer physicianpatient relationship, and less desire for autonomy also
$P<.01)$. Overall, patients who did not want to change physicians reported a significant decrease in trust compared with the change in trust reported by patients who found change to be acceptable (difference in change in trust $12.9, P<.001)$. This effect of mandated 


\begin{tabular}{|c|c|c|}
\hline Independent Variables* & $\begin{array}{l}\text { Including } \\
\text { Demographic } \\
\text { and Clinical } \\
\text { Variables } \\
(95 \% \mathrm{Cl})\end{array}$ & $\begin{array}{l}\text { Including Demographic } \\
\text { and Clinical Variables, } \\
\text { Plus Autonomy and } \\
\text { Length of Relationship } \\
\text { With Physician } \\
(95 \% \mathrm{Cl})\end{array}$ \\
\hline \multicolumn{3}{|l|}{ Group } \\
\hline $\begin{array}{l}\text { English-speaking Japanese } \\
\text { Americans }\end{array}$ & $13.6(10.2-17.0)$ & $16.6(13.25-20.04)$ \\
\hline $\begin{array}{l}\text { Japanese-speaking Japanese } \\
\text { Americans }\end{array}$ & $9.44(6.02-12.9)$ & $9.87(6.52-13.25)$ \\
\hline Female & $-2.88(-5.40--0.34)$ & $-2.16(-4.62-0.30)$ \\
\hline Age & $0.19(0.08-0.31)$ & $0.04(-0.08-0.16)$ \\
\hline \multicolumn{3}{|l|}{ Marital status } \\
\hline Divorced/separated & $-5.02(-9.38$ to -0.66$)$ & $-4.84(-9.18$ to -0.50$)$ \\
\hline Never married & $2.68(-2.71-8.07)$ & $2.05(-3.06-7.17)$ \\
\hline Widowed & $3.22(0.09-6.35)$ & $4.05(0.98-7.12)$ \\
\hline Education & $-0.40(-0.84-0.04)$ & $-0.28(-0.72-0.15)$ \\
\hline \multicolumn{3}{|l|}{ Religiosity } \\
\hline Religious, not a church member & $4.94(2.09-7.79)$ & $4.51(1.73-7.29)$ \\
\hline Religious, church member & $7.41(4.82-9.99)$ & $7.45(4.93-9.97)$ \\
\hline Physical summary score & $0.16(0.02-0.30)$ & $0.19(0.06-0.32)$ \\
\hline Mental summary score & $0.19(0.05-0.34)$ & $0.16(0.02-0.31)$ \\
\hline Hospitalization in past 6 months & $4.86(0.94-8.78)$ & $3.85(-0.04-7.73)$ \\
\hline Years with regular doctor & - & $2.94(2.07-3.80)$ \\
\hline Autonomy preference index & - & $-3.00(-4.12$ to -1.88$)$ \\
\hline \multicolumn{3}{|c|}{$\begin{array}{l}\text { Note: Coefficients presented from multiple linear regression model that includes demographic and clinical vari- } \\
\text { ables and has } n=876 \text { and adjusted } R^{2}=0.19 \text {. Model including demographics, clinical variables, autonomy and } \\
\text { physician relationship has } n=826 \text { and adjusted } R^{2}=0.26 \text {. }\end{array}$} \\
\hline \multicolumn{3}{|c|}{$\mathrm{Cl}=$ confidence interval; $\mathrm{HRQOL}=$ health-related quality of life. } \\
\hline \multicolumn{3}{|c|}{$\begin{array}{l}\text { * Independent variables have reference groups as follows: Group - Japanese living in Japan; female - male; age } \\
\text { - per year; marital status - married; education - per year; religiosity - not religious; physical HRQOL score - per } \\
\text { point on 100-point scale; mental HRQOL score - per point on 100-point scale; hospitalization in past } 6 \text { months - } \\
\text { no hospitalization; years with regular doctor - per year; Autonomy Preference Index - per point on 5-point scale. }\end{array}$} \\
\hline
\end{tabular}

to easy change in modulating trust. The presence of these characteristics, however, can alert physicians to attend to aspects of care that appear to be affected by trust, such as adherence to medications and therapeutic recommendations. ${ }^{4,5}$ With such patients, physicians may want to make special efforts to build trust, including recognizing the anxiety surrounding cultural barriers and facilitating communication. ${ }^{45}$

Patients who want to make their own decisions trust their physicians less. Physicians might enhance their relationship with patients who desire more autonomy over their health care decisions by adopting an interactive, less directive practice style. Although age has been shown in other studies ${ }^{10,20-22,24}$ to be a significant predictor of trust, adding autonomy preference to the demographic-clinical model removed the effect of age, suggesting that desire for autonomy mediates variation in trust by age.

Recognizing which patients are predisposed to be less trusting is the first step toward securing trust within the relationship. Divorced or separated patients might bring experiences of broken trust into the clinical encounphysician change on trust was unrelated to previous or current physician ethnicity (Table 5). In adjusted analyses accounting for patient characteristics and clinical variables, patients who did not want to change physicians suffered a loss of 15 trust points $(P<.001)$ compared with patients who were amenable to change.

\section{DISCUSSION}

This study of Japanese and Japanese Americans found that decreased patient desire for autonomy, being married, greater religiosity, and a physician-patient relationship of longer duration were associated with greater trust in one's physician. For Japanese American respondents, Western acculturation and patient-physician ethnic match were related to increased trust, whereas insurance-mandated physician change was associated with less trust. Many of these factors are not amenable ter. Less religious patients also reported less trust. Yet, the association between religiosity and trust should be viewed cautiously, because differences may exist in how Japanese living in Japan and Japanese Americans view religion. Self-reported religiosity may be affected by one's cultural framework; church attendance and membership may be a stronger indication of religiosity in the United States than in Japan. Consistent with previous studies, a physician-patient relationship of shorter duration was associated with less trust. ${ }^{10,20,24,28,29}$

Overall, English-speaking Japanese American respondents were more trusting than Japanese-speaking Japanese American respondents, who were more trusting than Japanese respondents living in Japan. The more acculturated Japanese American respondents may trust their physicians more because of a greater ease in communicating with physicians in English and an increased comfort with American physicians' manner- 
Table 4. Japanese Americans Only: Multivariate Models of Trust Including Acculturation and Physician Ethnicity

\begin{tabular}{|c|c|c|}
\hline Independent Variables* & $\begin{array}{l}\text { Demographic and } \\
\text { Clinical Variables } \\
(95 \% \mathrm{Cl})\end{array}$ & $\begin{array}{c}\text { Including Demographic } \\
\text { and Clinical Variables, Plus } \\
\text { Autonomy and Length of } \\
\text { MD Relationship } \\
(95 \% \mathrm{CI})\end{array}$ \\
\hline Female & $-2.43(-5.16-0.29)$ & $-1.77(-4.36-0.82)$ \\
\hline Age & $0.14(0.02-0.25)$ & $-0.052(-0.18-0.07)$ \\
\hline \multicolumn{3}{|l|}{ Marital status } \\
\hline Divorced/separated & $-7.25(-12.0$ to -2.54$)$ & $-6.75(-11.4$ to -2.07$)$ \\
\hline Never married & $1.62(-3.86-7.09)$ & $0.49(-4.74-5.72)$ \\
\hline Widowed & $2.98(-0.37-6.33)$ & $4.50(1.26-7.74)$ \\
\hline Education & $-0.12(-0.57-0.33)$ & $-0.07(-0.54-0.40)$ \\
\hline \multicolumn{3}{|l|}{ Religiosity } \\
\hline Religious, not a church member & $3.49(0.30-6.68)$ & $4.01(0.94-7.09)$ \\
\hline Religious, church member & $6.29(3.62-8.97)$ & $6.76(4.21-9.32)$ \\
\hline Physical summary score & $0.10(-0.04-0.24)$ & $0.14(0.00-0.28)$ \\
\hline Mental summary score & $0.28(0.13-0.43)$ & $0.25(0.10-0.40)$ \\
\hline Hospitalization in past 6 months & $4.37(0.13-8.60)$ & $4.31(0.06-8.57)$ \\
\hline \multicolumn{3}{|l|}{ Ethnicity of regular doctor } \\
\hline White & - & $-3.18(-6.01$ to -0.36$)$ \\
\hline Other ethnicity & - & $-6.46(-9.48$ to -3.44$)$ \\
\hline Years with regular doctor & - & $2.59(1.67-3.52)$ \\
\hline Autonomy Preference Index & - & $-2.70(-3.84$ to -1.57$)$ \\
\hline Acculturation score & - & $0.08(0.03-0.12)$ \\
\hline \multicolumn{3}{|c|}{$\begin{array}{l}\text { Note: Coefficients presented from multiple linear regression model that includes demographics and clinical vari- } \\
\text { ables has } n=705 \text { and adjusted } R 2=0.08 \text {. Model including demographics, clinical variables, autonomy and } \\
\text { physician relationship has } n=652 \text { and adjusted } R 2=0.19 \text {. }\end{array}$} \\
\hline \multicolumn{3}{|c|}{$\mathrm{MD}=$ physician $; \mathrm{Cl}=$ confidence interval $; \mathrm{HRQOL}=$ health-related quality of life. } \\
\hline \multicolumn{3}{|c|}{$\begin{array}{l}\text { * Independent variables have reference groups as follows: Group - Japanese living in Japan; female - male; age } \\
\text { - per year; marital status - married; education - per year; religiosity - not religious; physical HRQOL score - per } \\
\text { point on 100-point scale; mental HRQOL score - per point on 100-point scale; hospitalization in past } 6 \text { months } \\
\text { - no hospitalization; ethnicity of regular doctor - Japanese; years with regular doctor - per year; Autonomy Pref- } \\
\text { erence Index - per point on 5-point scale; acculturation score - per point on a 100-point scale. }\end{array}$} \\
\hline
\end{tabular}

isms and Western culture. This relationship of acculturation and trust is underscored by the relationship between ethnic match and trust. Yet, it is not realistic to achieve an ethnic match for all patients desiring one. Instead, cultural competency training might enhance patient trust by promoting understanding and acceptance of different cultural norms. ${ }^{45-49}$

This study raises the intriguing question of why Japanese American respondents, given the potential language and cultural barriers, report more trust in their physicians than do the Japanese respondents living in Japan. This difference may be related to response frame. Asian Americans, in general, tend to assign lower scores on physician-rating questionnaires than whites, Latinos, or African Americans ${ }^{50-52}$; perhaps Asians from other countries respond with lower scores than those living in the United States. Japanese, in particular, may hesitate to express strong feelings of positive or negative trust because of cultural inhibitions. Alternatively, the Japanese living in Japan might trust their physicians less

Table 5. Japanese Americans Only: Relationship of Changing Physicians and Physician (MD) Ethnicity With Trust in Physician

\begin{tabular}{|c|c|c|c|c|c|c|c|c|c|c|}
\hline \multirow[b]{2}{*}{$\begin{array}{l}\text { Previous } \\
\text { MD }\end{array}$} & \multirow[b]{2}{*}{$\begin{array}{l}\text { Current } \\
\text { MD }\end{array}$} & \multicolumn{4}{|c|}{ Did Not Want to Change MD } & \multicolumn{4}{|c|}{ OK to Change MD } & \multirow[b]{2}{*}{$\begin{array}{c}\text { Overall } \\
\text { Difference }\end{array}$} \\
\hline & & $\mathrm{n}$ & $\begin{array}{c}\text { Mean } \\
\text { Previous } \\
\text { MD } \\
\text { Trust }\end{array}$ & $\begin{array}{l}\text { Mean } \\
\text { Current } \\
\text { MD } \\
\text { Trust }\end{array}$ & Change & $\mathrm{n}$ & $\begin{array}{c}\text { Mean } \\
\text { Previous } \\
\text { MD } \\
\text { Trust }\end{array}$ & $\begin{array}{c}\text { Mean } \\
\text { Current } \\
\text { MD } \\
\text { Trust }\end{array}$ & Change & \\
\hline \multirow[t]{3}{*}{ Japanese } & Japanese & 46 & 88.9 & 85.8 & -3.1 & 32 & 74.7 & 79.2 & 4.5 & $7.6^{*}$ \\
\hline & White & 6 & 93.1 & 80.5 & -12.6 & 9 & 75.0 & 82.4 & 7.4 & 20.0 \\
\hline & Other & 6 & 91.7 & 68.1 & -23.6 & 6 & 66.7 & 68.1 & 1.4 & 25.0 \\
\hline \multirow[t]{3}{*}{ White } & Japanese & 7 & 89.3 & 85.7 & -3.6 & 6 & 61.1 & 80.6 & 19.5 & $43.1^{*}$ \\
\hline & White & 23 & 91.3 & 84.8 & -6.5 & 21 & 73.4 & 79.8 & 6.4 & $12.9 *$ \\
\hline & Other & 6 & 81.9 & 77.8 & -4.1 & 16 & 72.4 & 77.1 & 4.7 & 8.8 \\
\hline \multirow[t]{3}{*}{ Other } & Japanese & 4 & 85.4 & 72.9 & -12.5 & 3 & 63.9 & 83.3 & 19.4 & 31.9 \\
\hline & White & 4 & 87.5 & 64.6 & -22.9 & 12 & 69.4 & 75.7 & 6.3 & $29.2^{\dagger}$ \\
\hline & Other & 10 & 89.2 & 75.8 & -13.4 & 16 & 66.7 & 65.6 & -1.1 & $12.3 *$ \\
\hline Overall & & 112 & 89.3 & 81.8 & $-7.5^{\ddagger}$ & 121 & 71.3 & 76.7 & $5.4^{\dagger}$ & $12.9^{\ddagger}$ \\
\hline $\begin{array}{l}* P \text { value }<. \\
\dagger P \text { value }<. \\
\ddagger P \text { value }<.\end{array}$ & & & & & & & & & & \\
\hline
\end{tabular}


than do Japanese Americans. Criticism by the Japanese media of inhibited communication within the physician-directed model of interaction in Japan could have eroded patient trust in their physicians. Further work should explore variations in trust between Japanese Americans and Japanese living in Japan.

These data also suggest that system factors affect trust in one's physician. Undesired switching of physicians as a result of insurance changes was associated with significantly reduced trust. These retrospective findings must be considered exploratory, however, employerbased health-plan changes directing patients to change physicians may not only be costly in terms of time to establish new relationships, ${ }^{8}$ they may actually harm care by diminishing trust among those resistant to change.

This study has several limitations. Despite efforts to reduce contextual differences between the English and Japanese language questionnaires, it is possible that some measurement differences persisted. Language and acculturation could affect the Likert response choices. Also, because the survey groups were drawn from urban settings, the respondents are not representative of all Japanese Americans or Japanese living in Japan, limiting the generalizability of the findings. English-speaking Japanese Americans were recruited from community centers in an area where Japanese Americans were highly concentrated, and it is possible these respondents were less acculturated than non-community-center members living outside the area. In addition, Japanese-speaking Japanese Americans were mostly older women living in communities densely populated by Japanese, although these communities were scattered over a wide geographic area. Studies of trust and ethnicity are needed on broader samples as well as with other cultural groups.

A smaller percentage of Japanese living in Japan completed the trust items than did English-speaking or Japanese-speaking Japanese Americans. Although response bias might contribute to the lower levels of trust reported by Japanese respondents living in Japan, their low response rate is more likely related to the structure of the Japanese health care system. As a result of universal insurance coverage, Japanese patients often have access to specialists or visit emergency departments instead of relying on care coordination by primary care physicians. Consistent with the $58 \%$ of Japanese respondents living in Japan who reported having a regular physician in this study, surveys have shown that about $60 \%$ of the Japanese population has a primary care physician.

Finally, this study is limited by its cross-sectional design. Its retrospective nature makes establishing a cause-effect link between mandated physician change and trust impossible. Those more satisfied with their new physician could have been more likely to report the change was acceptable compared with those who were less satisfied with their new physician.

These data expand our understanding of trust in the physician-patient relationship. They point out that such factors as religiosity, autonomy preference, and marital status are related to trust. Physicians should be aware that these factors might put their patients at risk for diminished trust, and specific attention might be focused toward building connections and confidence. The importance of cultural match emphasizes the crucial nature of cultural competency. It is important to note that physicians caring for less acculturated patients may garner less trust, but they should not be penalized by lower trust measures. Minimizing insurance shifts that force apart established physicianpatient relationships would enhance the trust physicians have established with their patients and may maximize the attendant clinical benefits.

To read or post commentaries in response to this article, see it online at http://www.annfammed.org/cgi/content/full/3/4/339.

Key words: Trust; acculturation; personal autonomy; physician-patient relations; Asian Americans

Submitted June 17, 2004; submitted, revised, December 8, 2004, accepted January 10, 2005.

Funding support: This study was supported by a grant from the VA/ UCLA/RAND Medical Treatment Effectiveness Program (MEDTEP) Center for Asians and Pacific Islanders which was funded by Agency for Health Care Policy Research (P5OHS07370). Additional project support was provided by Pfizer Foundation Grants to Support Joint International Research Projects in Japan. Dr. Tarn is a NRSA fellow under a training grant PE19001-09 from the Health Resources Services Administration.

Acknowledgments: The authors appreciate the collaboration of Takashi Makinodan, PhD, Sam Shimoguchi, and Nancy Harada, PhD. We thank the Japanese American Community Centers, specifically Mr. Michael Motoyasu, Mr. George Asawa, Mr. Leroy Kawai, and Keiro Services for help in arranging the focus groups. The authors appreciate the technical assistance of Todd Sasaki and Victor Gonzalez.

\section{References}

1. Crawshaw R, Rogers DE, Pellegrino ED, et al. Patient-physician covenant. JAMA. 1995;273:1553.

2. Montaglione CJ. The physician-patient relationship: cornerstone of patient trust, satisfaction, and loyalty. Manag Care Q. 1999;7:5-21.

3. Dunn L, Perry BL. Where your patients are. Prim Care. 1997;24:715-721.

4. Lau JT, Yu A, Cheung JC, Leung SS. Studies on common illnesses and medical care utilization patterns of adolescents in Hong Kong. J Adolesc Health. 2000;27:443-452.

5. Safran DG, Taira DA, Rogers WH, et al. Linking primary care performance to outcomes of care. J Fam Pract. 1998;47:213-220.

6. DiMatteo MR. Enhancing patient adherence to medical recommendations. JAMA. 1994;271:79-83.

7. Francis V, Korsch BM, Morris MJ. Gaps in doctor-patient communication. Patients' response to medical advice. N Engl J Med. $1969 ; 280: 535-540$ 
8. Mechanic $D$, Schlesinger $M$. The impact of managed care on patients' trust in medical care and their physicians. JAMA. 1996;275:1693-1697.

9. Mostashari F, Riley E, Selwyn PA, Altice FL. Acceptance and adherence with antiretroviral therapy among HIV-infected women in a correctional facility. J Acquir Immune Defic Syndr Hum Retrovirol. 1998; 18:341-348.

10. Thom DH, Ribisl KM, Stewart AL, Luke DA. Further validation and reliability testing of the Trust in Physician Scale. The Stanford Trust Study Physicians. Med Care. 1999;37:510-517

11. Thom DH, Kravitz RL, Bell RA, Krupat E, Azari R. Patient trust in the physician: relationship to patient requests. Fam Pract. 2002;19: 476-483.

12. Keating NL, Green DC, Kao AC, et al. How are patients' specific ambulatory care experiences related to trust, satisfaction, and consid ering changing physicians? J Gen Intern Med. 2002;17:29-39.

13. Grumbach K, Selby JV, Damberg C, et al. Resolving the gatekeeper conundrum: what patients value in primary care and referrals to specialists. JAMA. 1999;282:261-266.

14. Hall JA, Dornan MC. What patients like about their medical care and how often they are asked: a meta-analysis of the satisfaction literature. Soc Sci Med. 1988;27:935-939.

15. Kao AC, Green DC, Zaslavsky AM, Koplan JP, Cleary PD. The relationship between method of physician payment and patient trust. JAMA. 1998;280:1708-1714.

16. Gray BH. Trust and trustworthy care in the managed care era. Health Aff (Millwood). 1997;16:34-49.

17. Mechanic D. Changing medical organization and the erosion of trust Milbank Q. 1996;74:171-189.

18. Emanuel EJ, Dubler NN. Preserving the physician-patient relationship in the era of managed care. JAMA. 1995;273:323-329.

19. Relman AS. The impact of market forces on the physician-patient relationship. J R Soc Med. 1994;87 Suppl 22:22-24; discussion 24-25.

20. Kao AC, Green DC, Davis NA, Koplan JP, Cleary PD. Patients' trust in their physicians: effects of choice, continuity, and payment method. J Gen Intern Med. 1998;13:681-686.

21. Thom DH, Campbell B. Patient-physician trust: an exploratory study. J Fam Pract. 1997;44:169-176.

22. Thom DH. Physician behaviors that predict patient trust. J Fam Pract. 2001;50:323-328.

23. Scott RA, Aiken LH, Mechanic D, Moravcsik J. Organizational aspects of caring. Milbank Q. 1995;73:77-95.

24. Mainous AG, 3rd, Baker R, Love MM, Gray DP, Gill JM. Continuity of care and trust in one's physician: evidence from primary care in the United States and the United Kingdom. Fam Med. 2001;33:22-27.

25. Hall MA, Camacho F, Dugan E, Balkrishnan R. Trust in the medical profession: conceptual and measurement issues. Health Serv Res. 2002;37:1419-1439

26. Anderson LA, Dedrick RF. Development of the Trust in Physician scale: a measure to assess interpersonal trust in patient-physician relationships. Psychol Rep. 1990;67:1091-1100.

27. Mechanic D, Meyer S. Concepts of trust among patients with serious illness. Soc Sci Med. 2000;51:657-668

28. Doescher MP, Saver BG, Franks P, Fiscella K. Racial and ethnic disparities in perceptions of physician style and trust. Arch Fam Med. 2000;9:1156-1163.

29. Sullivan RJ, Menapace LW, White RM. Truth-telling and patient diagnoses. J Med Ethics. 2001;27:192-197.

30. Krupat E, Bell RA, Kravitz RL, Thom D, Azari R. When physicians and patients think alike: patient-centered beliefs and their impact on satis faction and trust. J Fam Pract. 2001;50:1057-1062.

31. Suinn R, Ahuna C, Khoo G. The Suinn-Lew Asian Self-Identity Acculturation scale: concurrent and factorial validation. Edu Psychol Meas. 1992;52:1041-1046.
32. Suinn R, Rickard-Figueroa K, Lew S, Vigil P. The Suinn-Lew Asian Self-Identity Acculturation scale: an initial report. Edu Psychol Meas. 1987;47:401-407.

33. Meredith L, Wenger N, Liu H, Harada N, Kahn K. Development of a brief scale to measure acculturation among Japanese-Americans. J Comm Psych. 2000;28:103-113.

34. Murphy ST, Palmer JM, Azen S, et al. Ethnicity and advance care directives. J Law Med Ethics. 1996;24:108-117.

35. Blackhall LJ, Murphy ST, Frank G, Michel V, Azen S. Ethnicity and attitudes toward patient autonomy. JAMA. 1995;274:820-825.

36. A controlled trial to improve care for seriously ill hospitalized patients. The study to understand prognoses and preferences for outcomes and risks of treatments (SUPPORT). The SUPPORT Principal Investigators. JAMA. 1995;274:1591-1598.

37. Bito S, Matsumura S, Fukuhara S, Wenger NS. Acculturation and end-of-life-decision making: focus group comparison of Japanese and Japanese-Americans. J Gen Intern Med. 1998;13(Suppl 1):93.

38. Ware JE, Kosinski M, SD K. SF12: How to Score the SF-12 Physical and Mental Health Summary Scales. Boston, Mass: New England Medical Center, The Health Institute; 1995.

39. Ware J, Snow K, Kosinski M, Gandek B. SF-36 Health Survey Manual and Interpretation Guide. Boston, Mass: New England Medical Center, The Health Institute; 1993.

40. Fukuhara S, Bito S, Green J, Hsiao A, Kurokawa K. Translation, adaptation, and validation of the SF-36 Health Survey for use in Japan. J Clin Epidemiol. 1998;51:1037-1044.

41. Ende J, Kazis L, Ash A, Moskowitz MA. Measuring patients' desire for autonomy: decision making and information-seeking preferences among medical patients. J Gen Intern Med. 1989;4:23-30.

42. Ohki M, Fukuhara S. Development and validation of the autonomy preference index for Japanese subjects. Japan Health Psychol. 1995;3:11-24.

43. Matsumura S, Bito S, Liu H, et al. Acculturation of attitudes toward end-of-life care: a cross-cultural survey of Japanese Americans and Japanese. J Gen Intern Med. 2002;17:531-539.

44. Organisation for Economic Cooperation and Development (OECD). Purchasing power parity. Consumer price levels. 2001. Available at: http://www.oecd.org/pdf/M00009000/M00009294.pdf. Accessed: May 16, 2002

45. Kagawa-Singer M, Blackhall LJ. Negotiating cross-cultural issues at the end of life: "You got to go where he lives". JAMA. 2001;286:2993-3001.

46. Brach C, Fraser I. Can cultural competency reduce racial and ethnic health disparities? A review and conceptual model. Med Care Res Rev. 2000;57 Suppl 1:181-217.

47. Crandall SJ, George G, Marion GS, Davis S. Applying theory to the design of cultural competency training for medical students: a case study. Acad Med. 2003;78:588-594

48. Scott CJ. Enhancing patient outcomes through an understanding of intercultural medicine: guidelines for the practitioner. Md Med J. 1997;46:175-180.

49. Thompson WL, Thompson TL, 2nd, House RM. Taking care of culturally different and non-English speaking patients. Int J Psychiatry Med. $1990 ; 20: 235-245$.

50. Taira DA, Safran DG, Seto TB, et al. Asian-American patient ratings of physician primary care performance. J Gen Intern Med. 1997;12:237242.

51. Meredith LS, Siu AL. Variation and quality of self-report health data. Asians and Pacific Islanders compared with other ethnic groups. Med Care. 1995;33:1120-1131.

52. Murray-Garcia JL, Selby JV, Schmittdiel J, Grumbach K, Quesenberry $C P, J r$. Racial and ethnic differences in a patient survey: patients' values, ratings, and reports regarding physician primary care performance in a large health maintenance organization. Med Care. 2000;38:300-310. 